\title{
Experimentation on Geopolymer Concrete Added with Silica Fume
}

\author{
Anish C, Sathish Kumar K, Rajesh S
}

\begin{abstract}
Concrete is the world's generally versatile, solid and dependable improvement material. Close by water, concrete is the most utilized material, which required enormous proportions of OPC. Standard OPC creation is the second just to the vehicle as the basic generator of carbon di oxide, which dirtied the earth. Notwithstanding that colossal all out criticalness was in like way devoured for the strong creation. Along these lines, it is unavoidable to locate an elective material to the current generally over the top, most asset debilitating OPC. Geopolymer bond is a creative headway material which will be passed on by the produced development of inorganic particles.This paper quickly outlines the constituents of geopolymer solid, its quality and potential applications.
\end{abstract} Concrete

Keywords - Ordinary Portland cement, Geopolymer bond,

\section{INTRODUCTION}

During the ongoing decades, incredible steps have been taken in improving the presentation of concrete as a development material[1]-[5]. Especially Silica Fume and fly debris independently or in a mix are vital underway of high quality cement for useful application. The utilization of silica smolder as a pozzolana has expanded overall consideration over the ongoing years since when appropriately utilized it as certain percent, it can upgrade different properties of cement both in the crisp just as in solidified states like before quality cohesiveness, quality, servitude porousness and toughness. The fundamental targets of utilizing fly debris in high quality cement are to decrease heat age and to acquire better solidness properties.

Stream sand which is most normally utilized as fine total in the creation of cement and mortar has the issue of intense lack and debasement issues in numerous regions. Simultaneously expanding amount of squashed stone is accessible from smashers as smasher sand. In the event that it is conceivable to utilize this squashed stone residue in making cement and mortar by incomplete/full substitution of characteristic stream sand, at that point this won't just spare the expense of development and yet it will take care of the issue of transfer of this residue[6]-[10].

Revised Manuscript Received on October 22, 2019

Anish C, Department of Civil Engineering, Bharath Institute of Higher Education and Research, Chennai , India. Email anishdavidpaul@gmail.com

Sathish Kumar K, Department of Civil Engineering, Bharath Institute of Higher Education and Research, Chennai , India. Email: sathish_4549@yahoo.co.in

Rajesh S, Department of Civil Engineering, Bharath Institute of Higher Education and Research, Chennai, India. Email: rajeshskr06@gmail.com

\section{OBJECTIVE}

1. To investigate the workability \& strength characteristics . 2. To compare the results with the conventional concrete.

3 . The mixes of grade $\mathrm{M} 30$ by replacing $0,5,10$, what's more, 15 percent of the mass of bond with silica smoke and fly debris utilizing a superplasticizer.

4. Additionally, an endeavor is made to locate the ideal bond trade level by SF for better quality attributes of cement.

5. To think about the consequences of both the silica smolder fly debris concrete with the regular cement[11]-[16].

\section{A. Scope}

This investigation centers around the properties of Silica vapor on superior cement to yield prior quality. And furthermore researched the investigation of fly debris properties in cement to yield quality and cost by monetarily. Among the properties we examined for the compressive quality on concrete while keeping up the functionality[17]-[22].

\section{B. Silica fume}

Silica fume is an exceptionally responsive material that is utilized in generally modest quantities to improve the properties of cement. It is a side-effect of creating certain metals in electric heaters.

\section{RESULT AND DISCUSSION}

Pressure test was completed on cubic examples. The size of the example is $150 \mathrm{~mm} \times 150 \mathrm{~mm} \times 150 \mathrm{~mm}$. three example for each time of cement were tried and the quality was acquired by normal. The individual variety of example was not more than $\pm 15 \%$ of the normal. The example put away in water were tried promptly on the expulsion from network were cleared off the examples and any anticipating pins expelled[23]-[28]. The dimension of the specimen and their weight were recorded before testing. The pressure testing machine was cleaned off and again different materials, which may interact with the pressure plates. While setting the $3 \mathrm{D}$ squares in the machine, care was taken with the end goal that the heap was applied to the contrary sides of the 3D shapes and not to top and base 


\begin{tabular}{|c|c|c|c|c|}
\hline Material & $\begin{array}{c}\text { strength } \\
\mathrm{N} / \mathrm{mm} 2\end{array}$ & $\begin{array}{c}\text { strength } \\
\mathrm{N} / \mathrm{mm} 2\end{array}$ & $\begin{array}{c}\text { strength } \\
\mathrm{N} / \mathrm{mm} 2\end{array}$ & $\begin{array}{c}\text { Avg. } \\
\text { strength } \\
\mathrm{N} / \mathrm{mm} 2\end{array}$ \\
\hline $\begin{array}{c}\text { silica fume } \\
5 \%\end{array}$ & 25.48 & 24.52 & 23.46 & 24.48 \\
\hline $\begin{array}{c}\text { silica fume } \\
10 \%\end{array}$ & 26.15 & 25.37 & 26.79 & 26.10 \\
\hline $\begin{array}{c}\text { silica fume } \\
15 \%\end{array}$ & 23.99 & 22.08 & 24.06 & 23.37 \\
\hline $\begin{array}{c}\text { Conventional } \\
\text { concrete }\end{array}$ & 22.52 & 26.87 & 26.05 & 25.14 \\
\hline
\end{tabular}

Table - 1 Compressive Strength Of Concrete Table 1, 3 Days

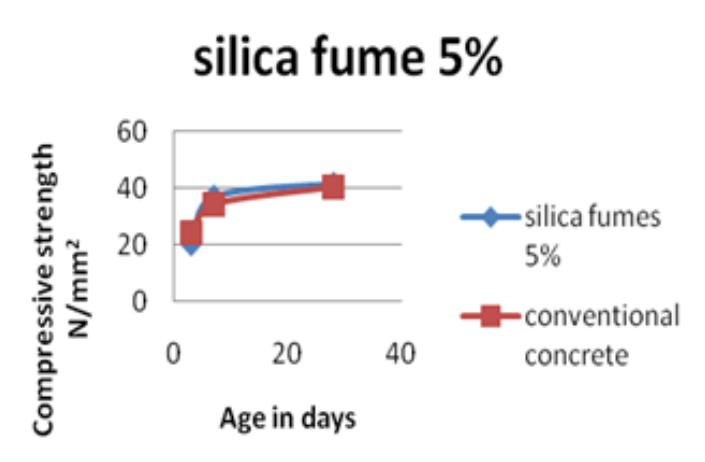

Figure - 1 Compressive Strength Of Concrete Table 1, 3 Days

\begin{tabular}{|c|c|c|c|c|}
\hline Material & $\begin{array}{c}\text { strength } \\
\mathrm{N} / \mathrm{mm} 2\end{array}$ & $\begin{array}{c}\text { strength } \\
\mathrm{N} / \mathrm{mm} 2\end{array}$ & $\begin{array}{c}\text { strength } \\
\mathrm{N} / \mathrm{mm} 2\end{array}$ & $\begin{array}{c}\text { Avg. } \\
\text { strength } \\
\mathrm{N} / \mathrm{mm} 2\end{array}$ \\
\hline $\begin{array}{c}\text { silica fume } \\
5 \%\end{array}$ & 35.68 & 33.46 & 33.31 & 34.15 \\
\hline $\begin{array}{c}\text { silica fume } \\
10 \%\end{array}$ & 35.28 & 34.98 & 35.37 & 35.21 \\
\hline $\begin{array}{c}\text { silica fume } \\
15 \%\end{array}$ & 33.56 & 32.94 & 34.70 & 33.73 \\
\hline $\begin{array}{c}\text { Conventional } \\
\text { concrete }\end{array}$ & 38.51 & 37.57 & 36.84 & 37.64 \\
\hline
\end{tabular}

Table - 2 Compressive Strength Of Concrete Table 2, 7 Days

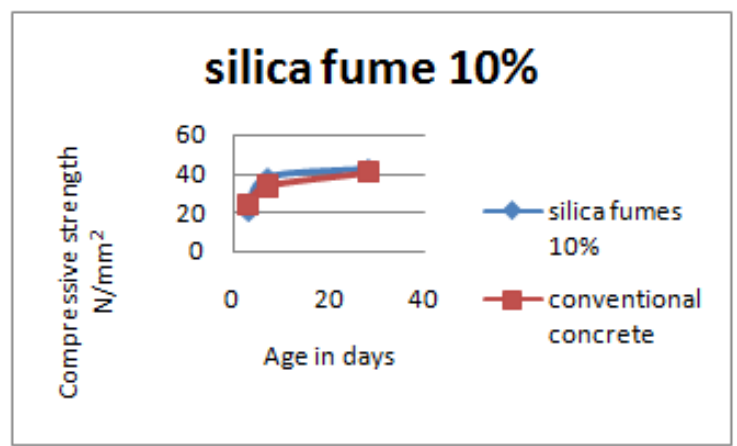

Figure - 1 Compressive Strength Of Concrete Table 2, 7 days

\begin{tabular}{|c|c|c|c|c|}
\hline Material & $\begin{array}{c}\text { strength } \\
\mathrm{N} / \mathrm{mm} 2\end{array}$ & $\begin{array}{c}\text { strength } \\
\mathrm{N} / \mathrm{mm} 2\end{array}$ & $\begin{array}{c}\text { strength } \\
\mathrm{N} / \mathrm{mm} 2\end{array}$ & $\begin{array}{c}\text { Avg. } \\
\text { strength } \\
\mathrm{N} / \mathrm{mm} 2\end{array}$ \\
\hline $\begin{array}{c}\text { silica fume } \\
5 \%\end{array}$ & 40.38 & 41.96 & 42.94 & 41.75 \\
\hline $\begin{array}{c}\text { silica fume } \\
10 \%\end{array}$ & 41.56 & 42.34 & 44.44 & 42.78 \\
\hline $\begin{array}{c}\text { silica fume } \\
15 \%\end{array}$ & 47.38 & 46.42 & 48.32 & 47.37 \\
\hline $\begin{array}{c}\text { Conventional } \\
\text { concrete }\end{array}$ & 40.23 & 41.68 & 40.14 & 40.68 \\
\hline
\end{tabular}

Table - 1 Compressive Strength Of Concrete Table 2, 14 Days

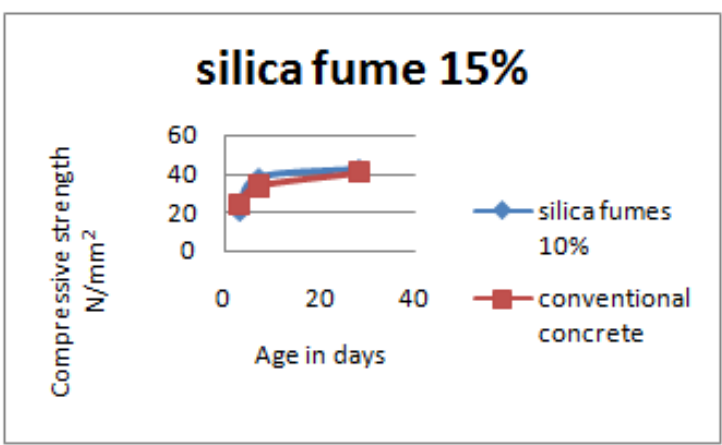

Figure - 1 Compressive Strength Of Concrete Table 2, 14 Days

\section{CONCLUSION}

Silca Fumes is introduced by reducing the cement content which increases the compressive strength of concrete. When compared with ordinary concrete in different curing dates [29]-[33]:

1. The strength in M30 grade when $15 \%$ of replacement increases, while conventional concrete has a decrease in strength from the graph.

2. From the result it is observed that the silica fume concrete gained a earlier strength than the conventional concrete.

3. Which gives the strong bondage in the concrete.

4. Cement can by replaced by $15 \%$ in M30 grade of concrete.

5. Both the physical and compound properties of microsilica and bond are in consistence with the standard aside from SO3 examined from concrete [34].

\section{REFERENCES}

1. Iyappan L., Dayakar P., Identification of landslide prone zone for coonoortalukusing spatial technology, International Journal of Applied Engineering Research,V-9,I-22,PP-5724-5732,Y-2014.

2. Kumar J., Sathish Kumar K., Dayakar P.,Effect of microsilica on high strength concrete, International Journal of Applied Engineering Research,V-9,I-22,PP-5427-5432,Y-2014.

3. Dayakar P., Vijay Ruthrapathi G., Prakesh J., Management of bio-medical waste, International Journal of Applied Engineering Research,V-9,I-22,PP-5518-5526,Y-2014.

4. Swaminathan N., Dayakar P., Resource optimization in construction project, International Journal of 
Applied Engineering Research,V-9,I-22,PP-5546-5551,Y-2014.

5. Venkat Raman K., Dayakar P., Raju K.V.B.,An experimental study on effect of cone diameters in penetration test on sandy soil, International Journal of Civil Engineering and Technology,V-8,I-8,PP-1581-1588,Y-2017.

6. Saritha B., Chockalingam M.P.,Photodradation of malachite green DYE using TIO2/activated carbon composite,International Journal of Civil Engineering and Technology,V-8,I-8,PP-156-163,Y-2017

7. Shendge R.B., Chockalingam M.P., Saritha B., Ambica A.,Swat modelling for sediment yield: A case study of Ujjani reservoir in Maharashtra, India,International Journal of Civil Engineering and Technology,V-9,I-1,PP-245-252,Y-2018

8. Chockalingam M.P., Balamurgan V.,Modernisation of an existing urban road-sector in Chennai, a case study report,International Journal of Civil Engineering and Technology,V-8,I-8,PP-1457-1467,Y-2017

9. Saritha B., Chockalingam M.P.,Adsorption study on removal of basic dye by modified coconut shell adsorbent, International Journal of Civil Engineering and Technology,V-8,I-8,PP-1370-1374,Y-2017

10. Saritha B., Chockalingam M.P.,Adsorptive removal of heavy metal chromium from aqueous medium using modified natural adsorbent,International Journal of Civil Engineering and Technology,V-8,I-8,PP-1382-1387,Y-2017

11. Chockalingam M.P., Palanivelraja S.,Retrospective analysis of a theoretical model used for forecasting future air quality near the north Chennai thermal power plant,International Journal of Civil Engineering and Technology,V-8,I-8,PP-1457-1467,Y-2017

12. Saritha B., Chockalingam M.P.,Photodegradation of methylene blue dye in aqueous medium by $\mathrm{Fe}-\mathrm{AC} / \mathrm{TiO} 2$ Composite,Nature Environment and Pollution Technology,V-17,I-4,PP-1259-1265,Y-2018

13. Shendge R.B., Chockalingam M.P., Kaviya B., Ambica A.,Estimates of potential evapotranspiration rates by three methods in upper Bhima Basin, In Maharashtra, India,International Journal of Civil Engineering and Technology,V-9,I-2,PP-475-480,Y-2018

14. Shendge R.B., Chockalingam M.P.,The soil and water assessment tool for Ujjani Reservoir,International Journal of Mechanical Engineering and Technology,V-9,I-2,PP-354-359,Y-2018

15. Shendge R.B., Chockalingam M.P.,A review on soil and water assessment tool,International Journal of Mechanical Engineering and Technology,V-9,I-2,PP-347-353,Y-2018

16. Sachithanandam P., Meikandaan T.P., Srividya T.,Steel framed multi storey residential building analysis and design,International Journal of Applied Engineering Research,V-9,I-22,PP-5527-5529,Y-2014

17. Meikandaan T.P., Ramachandra Murthy A.,Study of damaged RC beams repaired by bonding of CFRP laminates, International Journal of Civil Engineering and Technology,V-8,I-2,PP-470-486,Y-2017

18. Meikandaan T.P., Ramachandra Murthy A.,Retrofittng of reinforced concrete beams using GFRP overlays,International Journal of Civil Engineering and Technology,V-8,I-2,PP-423-439,Y-2017

19. Meikandaan T.P., Ramachandra Murthy A.,Flexural behaviour of RC beam wrapped with GFRP sheets,International Journal of Civil Engineering and Technology,V-8,I-2,PP-452-469,Y-2017

20. Meikandaan T.P., Murthy A.R.,Experimental study on strengthening of rc beams using glass Fiber,International Journal of Civil Engineering and Technology,V-9,I-11,PP-959-965,Y-2018

21. Meikandaan T.P., Hemapriya M.,Use of glass FRP sheets as external flexural reinforcement in RCC Beam,International Journal of Civil Engineering and Technology,V-8,I-8,PP-1485-1501,Y-2017

22. Saraswathy R., Saritha B.,Planning of integrated satellite township at Thirumazhisai,International Journal of Applied Engineering Research,V-9,I-22,PP-5558-5560,Y-2014

23. Saritha B., Ilayaraja K., Eqyaabal Z.,Geo textiles and geo synthetics for soil reinforcement,International Journal of Applied Engineering Research,V-9,I-22,PP-5533-5536,Y-2014

24. Ambica A., Saritha B., Changring G., Singh N B., Rajen M., Salman Md.,Analysis of groundwater quality in and around Tambaram taluk, Kancheepuram district,International Journal of Civil Engineering and Technology,V-8,I-8,PP-1362-1369,Y-2017

25. Arunya A., Sarayu K., Ramachandra Murthy A., Iyer N.R.,Enhancement of durability properties of bioconcrete incorporated with nano silica,International Journal of Civil Engineering and Technology,V-8,I-8,PP-1388-1394,Y-2017
26. Ilayaraja K., Krishnamurthy R.R., Jayaprakash M., Velmurugan P.M., Muthuraj S.,Characterization of the 26 December 2004 tsunami deposits in Andaman Islands (Bay of Bengal, India),Environmental

Earth

Sciences,V-66,I-8,PP-2459-2476,Y-2012

27. Ilayaraja K.,Morphometric parameters of micro watershed in Paravanar sub-basin, Cuddalore District,International Journal of Civil Engineering and Technology,V-8,I-8,PP-1444-1449,Y-2017

28. Ilayaraja K., Singh R.K., Rana N., Chauhan R., Sutradhar N.,Site suitability assessment for residential areas in south Chennai region using remote sensing and GIS techniques,International Journal of Civil Engineering and Technology,V-8,I-8,PP-1468-1475,Y-2017

29. Ilayaraja K., Reza W., Kumar V., Paul S., Chowdhary R.,Estimation of land surface temperature of Chennai metropolitan area using Landsat images,International Journal of Civil Engineering and Technology,V-8,I-8,PP-1450-1456,Y-2017

30. Chitra R.,Experimental study on beam using steel fiber and latex,International Journal of Civil Engineering and Technology,V-8,I-8,PP-1395-1403,Y-2017

31. Chitra R.,Analysis of traffic and management at Kovilambakkam intersection,International Journal of Civil Engineering and Technology,V-8,I-8,PP-1433-1443,Y-2017

32. Aswathy M.,Experimental study on light weight foamed concrete,International Journal of Civil Engineering and Technology,V-8,I-8,PP-1404-1412,Y-2017

33. Aswathy M.,Wastewater treatment using constructed wetland with water lettuce (Eichornia Crasipies),International Journal of Civil Engineering and Technology,V-8,I-8,PP-1413-1421,Y-2017

34. Kiruthiga K., Anandh K.S., Gunasekaran K, Assessment of influencing factors on improving effectiveness and productivity of construction engineers, 2015, International Journal of Applied Engineering Research, V - 10,I -17,p -13849-13854.

\section{AUTHORS PROFILE}

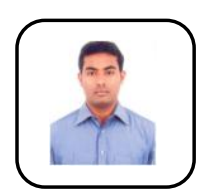

Anish C Assistant Professor, Department of Civi Engineering, Bharath Institute of Higher Education and Research, Chennai, India.

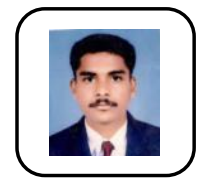

Sathish Kumar K Assistant Professor, Department of Civil Engineering, Bharath Institute of Higher Education and Research, Chennai , India.

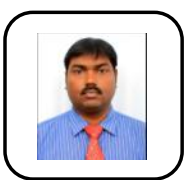

Rajesh S Assistant Professor, Department of Civi Engineering, Bharath Institute of Higher Education and Research, Chennai, India. 